African Crop Science Journal by African Crop Science Society is licensed under a Creative Commons Attribution 3.0 Uganda License. Based on a work at www.ajol.info/ and www.bioline.org.br/cs DOI: https://dx.doi.org/10.4314/acsj.v28i2.7

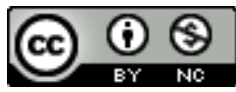

\title{
PATHOGENICITY AND VIRULENCE OF UGANDAN ISOLATES OF COMMON BACTERIAL BLIGHT DISEASE PATHOGEN (Xanthomonas spp.)
}

\author{
J.K. TUGUME ${ }^{1,2}$, C. OSUNDWA ${ }^{1}$, G. TUSIIME ${ }^{1}$, C.M. MUKANKUSI ${ }^{2}$, A.M. SSEKAMATE2 \\ P. WASSWA ${ }^{1}$ and R. BURUCHARA ${ }^{2}$ \\ ${ }^{1}$ Makerere University, Department of Agricultural Production. P. O. Box 7062, Kampala, Uganda \\ ${ }^{2}$ International Centre for Tropical Agriculture (CIAT)/Pan African Bean Research Alliance (PABRA), \\ P. O. Box 6247 , Kampala, Uganda \\ Corresponding author: tugume2006@yahoo.com
}

(Received 19 November 2019; accepted 27 June 2020)

\begin{abstract}
Breeding for resistance is a major component in the integrated management of common bacterial disease of beans (Phaseolus vulgaris L.). Use of less virulent strains or strains with attenuated virulence may lead to selection of resistant genotypes with intermediate response, when exposed to more virulent strains of the pathogen. The objective of this study to identify and characterise Ugandan isolates of common bacterial blight disease-causing pathogens for virulence. Bacteria were isolated from leaf samples collected from districts of Kabale, Masaka, Bukomansimbi, Mubende, Mbale, Bulambuli and Apac, all in Uganda, during the first season of 2016. The bacteria were tested for pathogenicity, as well as virulence on both breeding and local varieties. The study identified three most virulent isolates, namely MBL020, KAB-3 and BUL-14, all belonging to Xathomonas citri pv fuscans. These isolates are very similar to those previously identified from Uganda (NCPB 670 and NCCPB 1402) more than 50 years ago. The study further revealed that NAROBEAN1, NAROBEAN 2, NAROBEAN 4, VAX 3, VAX5 and NE 2- 14- 8 had better resistance compared to other tested genotypes.
\end{abstract}

Key Words: Phaseolus vulgaris, Uganda, virulent strains

\section{RÉSUMÉ}

La sélection pour la résistance est un élément majeur de la gestion intégrée des maladies bactériennes courantes des haricots (Phaseolus vulgaris L.). L'utilisation de souches moins virulentes ou de souches à virulence atténuée peut conduire à la sélection de génotypes résistants à réponse intermédiaire, lorsqu'ils sont exposés à des souches plus virulentes du pathogène. L'objectif de cette étude etait d'identifier et de caractériser les isolats ougandais de pathogènes causant la maladie bactérienne commune pour la virulence. Des bactéries ont été isolées à partir d'échantillons de feuilles prélevés dans les districts de Kabale, Masaka, Bukomansimbi, Mubende, Mbale, Bulambuli et Apac, tous en Ouganda, au cours de la première saison de 2016. Les bactéries ont été testées pour leur pathogénicité, ainsi que leur virulence à la fois pour la reproduction et variétés locales. L'étude a 
identifié les trois isolats les plus virulents, à savoir MBL020, KAB-3 et BUL-14, tous appartenant à Xathomonas citri pv fuscans. Ces isolats sont très similaires à ceux précédemment identifiés en Ouganda (NCPB 670 et NCCPB 1402), il y a plus de 50 ans. L'étude a en outre révélé que NAROBEAN1, NAROBEAN 2, NAROBEAN 4, VAX 3, VAX5 et NE 2- 14-8 avaient une meilleure résistance par rapport aux autres génotypes testés.

Mots Clés: Phaseolus vulgaris, Ouganda, souches virulentes

\section{INTRODUCTION}

Common bean (Phaseolus vulgaris L.) is a staple for millions of people around the world, and is one of the most traded commodity in eastern Africa (OEC, 2017, MFPED, 2018). However, the productivity of beans in the region, and Uganda in particular remains low due to devastating diseases, among which is common bacterial blight disease. Common bacterial blight (CBB) disease, caused by Xanthomonas spp., has been reported in Uganda for more than 60 years (Aritua et al., 2015); reducing yield by more than $40 \%$ under conditions of high disease pressure (Opio et al, 1993). CBB disease is mainly spread in eastern Africa through seed (Opio et al., 1996; Karavina et al., 2011 ).

Management of common bacterial blight is mainly through use of resistant varieties, in combination with other measures such as disease-free seed, field sanitation and crop rotation (Opio et al.,1996; Karavina et al., 2011). Host resistance is the most practical solution in the management of common bacterial blight disease. However, the development of disease-resistant varieties, with improved yields that are stable, is a challenge that is compounded by climate change and global trade that introduces new pathogen strains. The new bacterial strains resulting from introduction and/or pathogen evolution may compromise the existing resistance and breeding efforts. Bean grain trade may aid the movement and distribution of common bacterial blight pathogen strains to new areas, changing the diversity and disease pressure due to introduction of more virulent strains or pathotypes.
Opioet al. (1996) reported pathogenic variation in Ugandan populations of Xanthomonas spp. infecting beans. Variation in virulence has been observed in both Xanthomonas axonopodis pv. phaseoli and Xanthomonas fuscans sub fuscans. Use of less virulent strains or strains with attenuated virulence may lead to selection of resistant genotypes with intermediate response when exposed to more virulent strains (Duncan et al., 2011). This has already been observed on USDK CBB-15 and USWK-CBB-17 when exposed to a more aggressive Xcp25 (Viteri et al., 2014).

In Uganda, Alladassi et al. (2018) noted that some genotypes like ADP660 that had high resistance in the screen house, became moderately resistant when exposed to field conditions; which points to existence of more aggressive and virulent strains in Uganda's fields. The East African strains of Xanthomonas axonopodis pv. phaseoli and Xanthomonas fuscans sub fuscans have been reported to be more virulent in some studies and less in others (Schuster et al., 1973; Gilbertson et al, 2008; Gilbertson, 2011 ) The purpose of this study was to identify more virulent Ugandan isolates of Xanthomonas that could be used in selection of bean genotypes with high level of resistance to $\mathrm{CBB}$.

\section{MATERIALS AND METHODS}

Isolation of bacterial pathogens. Bacteria were isolated from leaf samples collected from districts of Kabale, Masaka, Bukomansimbi, Mubende, Mbale, Bulambuli and Apac in Uganda during a disease survey of farmers' fields, conducted in the first cropping season 
of 2016. Isolation and identification of the pathogen were done at the National Biotechnology Laboratory at Kawanda, using established CIAT protocol (Guillermo et al., n.d). The infected materials were rinsed under running tap water for $10 \mathrm{~min}$, surfaced sterilised for $3 \mathrm{~min}$ in $3.5 \%$ sodium hypochlorite, and then rinsed twice in sterile water for $1 \mathrm{~min}$ each.

Leaf materials were macerated and incubated overnight at $5{ }^{\circ} \mathrm{C}$ in a $1 \mathrm{ml}$ Saline solution, for 16 hours. Using an inoculation loop, streaking was done on Nutrient agar (NA). Plates were incubated at $28{ }^{\circ} \mathrm{C}$ for 48 hours. Following the 48 hours incubation period, yellow-pigmented colonies typical of Xanthomonas spp., were purified on YDC, agar by a series of single colony transfers. Pure colonies were then suspended in $80 \%$ glycerol for long term storage at $-80{ }^{\circ} \mathrm{C}$.

Identification of bacteria. The isolated bacteria were identified using a combination of phenotypic and Molecular methods. Phenotypically, bacterial colonies were identified on YCDA based on yellowpigmentation and mucoid nature, which is typical of Xanthomonas spp. After $48 \mathrm{hr}$ of growth, genomic DNA was extracted from yellow pigmented colonies using a quick fungal/bacterial kit (Zymo research, Irvine, California).

The colonies were further confirmed through PCR, using a set of two specific primers (Gyr-R1 5' cttgaagcgctgtacetg 3', Gyr-L1 5' taccetgctgctgacatt 3' targeting the gyraseB gene) and R1 5' gttgacgccgaactggta 3 ' and Fyu-L15' gacgtcaacgcaccetac 3' targeting Fyugene of Xanthomonas. The PCR reaction contained $0.5 \mathrm{ul}$ each primer, $1 \mathrm{ul}$ of DNA and $22 \mu \mathrm{l}$ water of to make the final volume of $25 \mu \mathrm{l}$. The cycling conditions were as follows: (95'1 $\mathrm{min}, 95^{\prime} 30 \mathrm{~s}, 60^{\prime} 1 \mathrm{~min}$, 72 '30 s, 72's for 35 cycles). The only isolates that tested positive for PCR were used in the pathogenicity and virulence tests.
Pathogenicity tests. The 22 bacterial isolates that were PCR positive for gyrase and fyu gene were functionally characterised for their pathogenicity and virulence on susceptible genotype Kanyebwa, and later on other bean genotypes that included VAX 1, VAX 2, VAX 3 , VAX 4, VAX 5, VAX 6, MCM 2001, Montcalm and VTT923.Three bean plants were planted in 5-litre buckets containing sterilised soil in screen house at ambient temperatures for 18 days (Guillermo et al., n.d).

Three days prior to inoculation of plants, the bacterial inocula was prepared by first reactivating frozen bacterial stocks on YCDA medium for 48 hours. Bacterial culture for each isolate was then prepared by scooping the bacterial cells from the plate using a spatula and suspending them in $15 \mathrm{ml}$ of $0.5 \mathrm{X}$ PBS buffer. The bacterial concentration was then adjusted to a working concentration of $\sim 0.05 \mathrm{OD}_{600}$, after using the Nano drop to measure absorbances.

Inoculation was done using the razor blade method. The inoculations were mainly done between 5 and $7 \mathrm{pm}$, to avoid high temperatures that could kill the bacteria. Inoculated plants were scored for disease severity on day 14 after inoculation for foliar disease rating. The CIAT disease rating scale of 1-9 (1 to 3 indicate a resistant plant, 4 to 6 indicate a plant with an intermediate $\mathrm{r}$, and 7 to 9 indicate a susceptible plant eaction (Guillermo et al., n.d.).

Phylogenetic analysis. Bacterial strains of the three most virulent isolates, namely MBL020, BUL14 and KAB-3, were reactivated from freeze stocks by streaking onto YCDA plates and incubating at $28{ }^{\circ} \mathrm{C}$. Individual colonies were then re-streaked twice to limit possible contamination. After $48 \mathrm{hr}$ of growth, genomic DNA was extracted using quick fungal/bacterial kit (Zymo research, Irvine, California). 
The DNA from the three isolates was amplified using 16s ribosomal RNA Primer. The PCR reaction contained $0.5 \mu \mathrm{l}$ each primer, $1 \mathrm{ul}$ of DNA and $22 \mu \mathrm{l}$ water of to make the final volume of $25 \mu \mathrm{l}$. Amplification of the DNA sequences was conducted in a thermocycler (appendof) for 95' $1 \mathrm{~min}, 95^{\prime} 30$ s, 60' $1 \mathrm{~min}, 72$ '30 s,72's for 35 cycles. To determine the phylogenetic relationships of the virulent isolates with other Xanthomonas spp., a total of 11 nucleotide sequences were used in the analysis (Table 1). Raw sequence data of newly isolated bacteria were trimmed, and assembled using MEGAX alignment explorer.

Additional 16s ribosomal sequences of Xanthomonas were mined from online databases (NCBI). Sequences were aligned using CLUSTALW, implemented in MEGAX (Tamura et al., 2018). The evolutionary distances were computed using the Maximum Composite Likelihood method (Tamura et al., 2004) and are in units of the number of base substitutions per site. A Phylogenetic tree was constructed using UPGMA.

Data analysis. Virulence of the pathogen isolates was analysed by computing average disease scores of each pathogen isolate on each genotype tested. Based on the disease scores, the isolates with high disease scores were categorised as more virulent; while those with low disease scores were considered to be less virulent. The number of genotyped infected by each genotype was used as a measure of pathogenicity of the isolate.

Isolates with high disease scores infecting more genotypes were considered more pathogenic. The relationship between disease severity in the field and screen house was done graphically by plotting both disease scores of each isolate on the same graph.

Evaluation for CBB resistance. One of the most virulent and adapted isolates (MBL020) was used to evaluate 34 genotypes comprising of breeding germplasm (9) and local varieties (25), along side resistant checks (2) and susceptible (2) checks. The plants and inoculum were prepared as already described under the pathogenicity test section. Inoculation was done using the razor blade method for foliar; while the needle method was used for pods (Alladasi et al., 2018).

Inoculated plants were scored for disease severity on day 10 and 14 after inoculation for pod and foliar disease rating, respectively. The CIAT disease rating scale of 1-9 (Guillermo et al., n.d.). Virulence of MBL020 was further

TABLE 1. Bacterial isolates used in phylogenetic analysis

\begin{tabular}{|c|c|c|c|c|}
\hline Bacterial ID & Taxonomic ID & Host & $\begin{array}{l}\text { Year of } \\
\text { isolation }\end{array}$ & Country \\
\hline KAB-3 & UKNOWN & P. vulgaris & 2016 & Uganda \\
\hline MBLO20 & UKNOWN & P. vulgaris & 2016 & Uganda \\
\hline BUL014 & UKNOWN & P. vulgaris & 2016 & Uganda \\
\hline LMG 832 (NCPPB 670) & X. citripv. fuscans & P. vulgaris & 1958 & Uganda \\
\hline LMG7479(NCPPB 1402) & X. citripv. fuscans & P. vulgaris & 1962 & Uganda \\
\hline LMG8012(NCPPB1680) & $X$. axonopodis & P. vulgaris & 1964 & Tanzania \\
\hline KNUC393 & $X$. axonopodis & Paper rhizosphere & 2006 & Korea \\
\hline LMG538 & $X$. axonopodis & & & \\
\hline LMG 826 & X. fuscans & P. vulgaris & 2014 & Belgium: \\
\hline R-22578 & $X$. axonopodispoinsettiicola & Poinsettia & & China \\
\hline XAP-1 & $X$. axonopodispoinsettiicola & Poinsettia & & Taiwan \\
\hline
\end{tabular}

ID = Identification 
tested on genotypes containing QTL markers SU91 + SU91 (VAX 3, VAX 5, RWR 2154, ADP660) and SAP6 (Montcalm, VAX 1, VAX 2, Montcalm and MCM 2001).

Data analysis. Virulence of MBL020 isolate on breeding germplasm and local cultivars was analysed by comparing mean disease ratings on each genotype, and also using box plot analysis (Thirumalai and Manickam, 2017). Foliar disease rating was compared with pod disease rating through a correlation analysis. Based on both foliar and pod disease ratings, genotypes were classified as susceptible (69), moderately resistant (4-5) and resistant (13.) (Duncan et al., 2011; Castellanos et al., n.d.)

\section{RESULTS}

Pathogenicity and virulence of isolates. The study identified 22 bacterial isolates as Xanthomonas spp. based on phenotypic and PCR categorisation (Table 2). The isolated bacteria comprised of fuscous type 54.5 and $45.5 \%$ phaseoli. The bacteria were isolated from fields varying in incidence and severity, in the different agro-ecologies (Table 2). The bacteria were isolated from different varieties which included; Black (s), Kanyebwa, Nambale (s), Mugagawale, NABE 12C, K20, white (s) and unknown verities. The highest foliar disease severities in the field were recorded on varieties Mugagawale, 7.6, White small (NABE 6) 7.4 and Nambale small (NABE 16).

The study revealed that $95 \%$ of the isolates confirmed through PCR, were pathogenic on the universally susceptible Kanyebwa. At least each agro-ecology had an isolate with disease score (disease score $>7$ ). Isolates BUL14, BUL 15 and KAB-3 induced the highest disease scores when compared with other isolates (Table 2). The virulence of the isolates ranged from low to high, with disease scores ranging from 3-9 on the universally susceptible genotype, Kanyebwa.
Two isolates, MBL020 and KAB-3, were universally pathogenic infecting $9 / 9$ of the tested genotypes, most of which considered resistant to $\mathrm{CBB}$. Isolate MSK005 was also highly pathogenic, infecting 7/9 tested genotypes. Most isolates $(87.0 \%)$ of the isolates tested were only pathogenic on two genotypes (Kanyebwa and VTT923), of the 9 tested genotypes (Table 3). Isolates from Virulence of isolates in screen house were not correlated with virulence in the field where the pathogens were isolated (Fig. 1). Screen house disease severity scores were slightly higher (5.8) than field disease severity scores.

Phylogeny of most virulent isolates. The isolates analyses were grouped into two clusters; one containing mainly isolates from Uganda, and the other cluster contained isolates from other countries. The study revealed that the isolates MBL020, KAB-3 and BUL14 clustered together with isolates NCPPB 1402 and NCPPB 670. However, MBL020, KAB-3 and BUL14 were more similar when compared to 1402 and NCPPB 670 (Fig. 2). Surprisingly, isolate LMG 826 Xanthomonas fuscans from Belgium, clustered closer to Xanthomonas axonopodis pv. Poinsettiicola isolated from Poinsettia than to the Ugandan cluster of fuscan isolates from Phaseolus vulgaris.

Reactions to MBL020 isolate of Xanthomonas citri pvfuscans. The isolate was less aggressive on germplasm compared to local varieties (Fig. 3). Intermediate resistance with foliar disease rating varied from 4-6.5 on leaves and 4.8-6 on pods at 14 days after inoculation (DAI) (Fig. 3). The disease rating for local varieties was higher than that of breeding materials, ranging from 3-9 and 3-8 for leaves and pods, respectively (Fig. 3).

The isolate was less aggressive on genotype NE 2-14-8, which had the lowest disease rating on foliage of all the tested breeding material (Table 4). This isolate was also less 
TABLE 2. Identity, pathogenicity and virulence of bacterialisolated in this study

\begin{tabular}{|c|c|c|c|c|c|c|c|}
\hline Agro-ecology & Isolate & Bean variety & Isolate identity & Field incidence & Field severity & $\begin{array}{c}\text { Screen house } \\
\text { severity }\end{array}$ & $\begin{array}{l}\text { No. of infected } \\
\text { genotypes }\end{array}$ \\
\hline SWGF & BMS -TC & Unknown & Fuscan & 15 & 4.5 & 4.5 & $\mathrm{O} 2$ \\
\hline \multirow[t]{4}{*}{ NMF } & APA10-1 & Black (s) & Phaseoli & 40 & 5.9 & 7.0 & $\mathrm{O} 2$ \\
\hline & APA10-2 & Black (s) & Fuscan & 40 & 5.9 & 4.0 & $\mathrm{O} 2$ \\
\hline & APA005 & Unknown & Fuscans & 65 & 6.3 & 4.0 & $\mathrm{O} 2$ \\
\hline & AP 004 & White (s) & Fuscans & 80 & 7.4 & 4.0 & $\mathrm{O} 2$ \\
\hline \multirow[t]{3}{*}{ CV\&MF } & MSK002 & Kanyebwa & Phaseoli & 30 & 5.6 & 4.5 & $\mathrm{O} 2$ \\
\hline & MSK005 & Kanyebwa & Phaseoli & 10 & 3.4 & 6.0 & 05 \\
\hline & MSK009 & Nambale (s) & Phaseoli & 60 & 7.0 & 4.0 & $\mathrm{O} 2$ \\
\hline \multirow[t]{2}{*}{ SW } & KBL005 & Unknown & Phaseoli & 1 & 2.7 & 6.0 & $\mathrm{O} 2$ \\
\hline & KAB-3 & Nambale (s) & Fuscans & 30 & 6.1 & 8.3 & O6 \\
\hline \multirow[t]{9}{*}{$\mathrm{EF}$} & MBL020 & Mugagawale & Fuscans & 30 & 4.5 & 7.0 & 09 \\
\hline & BUL009 & Unknown & Fuscans & 15 & 6.8 & 4.0 & $\mathrm{O} 2$ \\
\hline & MBL013 & Kanyebwa & Phaseoli & 15 & 4.5 & 4.3 & $\mathrm{O} 2$ \\
\hline & MBL005 & Mugagawale & Fuscans & 3 & 5.6 & 7.0 & $\mathrm{O} 2$ \\
\hline & BUL008 & NABE $12 \mathrm{C}$ & Phaseoli & 20 & 5.0 & 4.0 & $\mathrm{O} 2$ \\
\hline & BUL014 & NABE $12 \mathrm{C}$ & Fuscans & 5 & 3.4 & 9.0 & $\mathrm{O} 2$ \\
\hline & BUL15-1 & NABE 7 & Fuscans & 1 & 2.3 & 8.0 & $\mathrm{O} 2$ \\
\hline & MBL006 & Mugagawale & Fuscans & 100 & 7.6 & 9.0 & $\mathrm{O} 2$ \\
\hline & MBL024 & Mugagawale & Fuscans & 2 & 2.2 & 3.0 & 02 \\
\hline \multirow[t]{3}{*}{ CWS } & MBE004 & K20 & Phaseoli & 60 & 5.4 & 5.0 & 03 \\
\hline & MBE003 & White (s) & Phaseoli & 10 & 5.0 & 7.0 & 02 \\
\hline & MBE002-1 & Nambale (s) & Phaseoli & 50 & 4.5 & 7.0 & 02 \\
\hline
\end{tabular}


TABLE 3. Reaction of Ugandan isolates of CBB on selected bean genotypes

\begin{tabular}{|c|c|c|c|c|c|c|c|c|c|c|c|}
\hline \multirow[t]{2}{*}{ Isolate ID } & \multirow[t]{2}{*}{ Agro-ecology } & \multicolumn{9}{|c|}{ CBB foliar rating (1-9) } & \multirow[b]{2}{*}{ *Kanyebwa } \\
\hline & & VAX1 & VAX2 & VAX3 & VAX4 & VAX5 & VAX6 & Montcalm & MCM2001 & VTT923 & \\
\hline BMS-TC & SWGF & 1 & 1 & 1 & 1 & 1 & 1 & 4 & 1 & 5 & 4.5 \\
\hline APA010 & NMF & 1 & 1 & 1 & 1 & 1 & 1 & 1 & 1 & 4 & 4.0 \\
\hline MSK002 & CV\&MF & 1 & 1 & 1 & 1 & 1 & 1 & 1 & 1 & 3 & 4.5 \\
\hline MBL020 & $\mathrm{EF}$ & 7 & 7 & 4 & 5.6 & 5.0 & 4.7 & 6 & 7 & 6 & 7.0 \\
\hline MBE004 & CWS & 1 & 1 & 1 & 1 & 1 & 3.0 & 1 & 1 & 5 & 5.0 \\
\hline MSK005 & $\mathrm{CV} \& \mathrm{MF}$ & 4 & 5 & 1 & 1 & 4 & 5.0 & 5 & 5 & 6 & 6.0 \\
\hline MSK009 & CV\&MF & 1 & 1 & 1 & 1 & 1 & 1 & 1 & 1 & 4 & 4.0 \\
\hline KBL005 & $\mathrm{EF}$ & 1 & 1 & 1 & 1 & 1 & 1 & 1 & 1 & 4 & 6.0 \\
\hline BUL009 & $\mathrm{EF}$ & 1 & 1 & 1 & 1 & 1 & 1 & 1 & 1 & 4 & 4.0 \\
\hline APA005 & $\mathrm{EF}$ & 1 & 1 & 1 & 1 & 1 & 1 & 1 & 1 & 4 & 4.0 \\
\hline MBE003 & CWS & 1 & 1 & 1 & 1 & 1 & 1 & 1 & 1 & 4 & 7.0 \\
\hline MBL013 & $\mathrm{EF}$ & 1 & 1 & 1 & 1 & 1 & 1 & 1 & 1 & 4 & 4.3 \\
\hline MBL005 & $\mathrm{EF}$ & 1 & 1 & 1 & 1 & 1 & 1 & 1 & 1 & 4 & 7.0 \\
\hline BUL008 & $\mathrm{EF}$ & 1 & 1 & 1 & 1 & 1 & 1 & 1 & 1 & 4 & 4.0 \\
\hline XAP1680 & $\mathrm{TZ}$ & 1 & 1 & 1 & 1 & 1 & 1 & 1 & 1 & 3 & 8.0 \\
\hline BUL014 & $\mathrm{EF}$ & 1 & 1 & 1 & 1 & 1 & 1 & 1 & 1 & 3 & 9.0 \\
\hline BUL15-1 & $\mathrm{EF}$ & 1 & 1 & 1 & 1 & 1 & 1 & 1 & 1 & 4 & 8.0 \\
\hline APA10-1 & $\mathrm{NMF}$ & 1 & 1 & 1 & 1 & 1 & 1 & 1 & 1 & 4 & 7.0 \\
\hline MBL006 & $\mathrm{EF}$ & 1 & 1 & 1 & 1 & 1 & 1 & 1 & 1 & 4 & 9.0 \\
\hline MBE002-1 & CWS & 1 & 1 & 1 & 1 & 1 & 1 & 1 & 1 & 4 & 7.0 \\
\hline APA004 & $\mathrm{NMF}$ & 1 & 1 & 1 & 1 & 1 & 1 & 1 & 1 & 4 & 4.0 \\
\hline MBL024 & $\mathrm{EF}$ & 1 & 1 & 1 & 1 & 1 & 1 & 1 & 1 & 4 & 3.0 \\
\hline KAB-3 & SW & 4.8 & 4.1 & 3.2 & 4.5 & 3.1 & - & - & 6.2 & - & 8.3 \\
\hline
\end{tabular}

*The isolates were tested on two separate occasions on genotype Kanyebwa before being tested on other genotype 


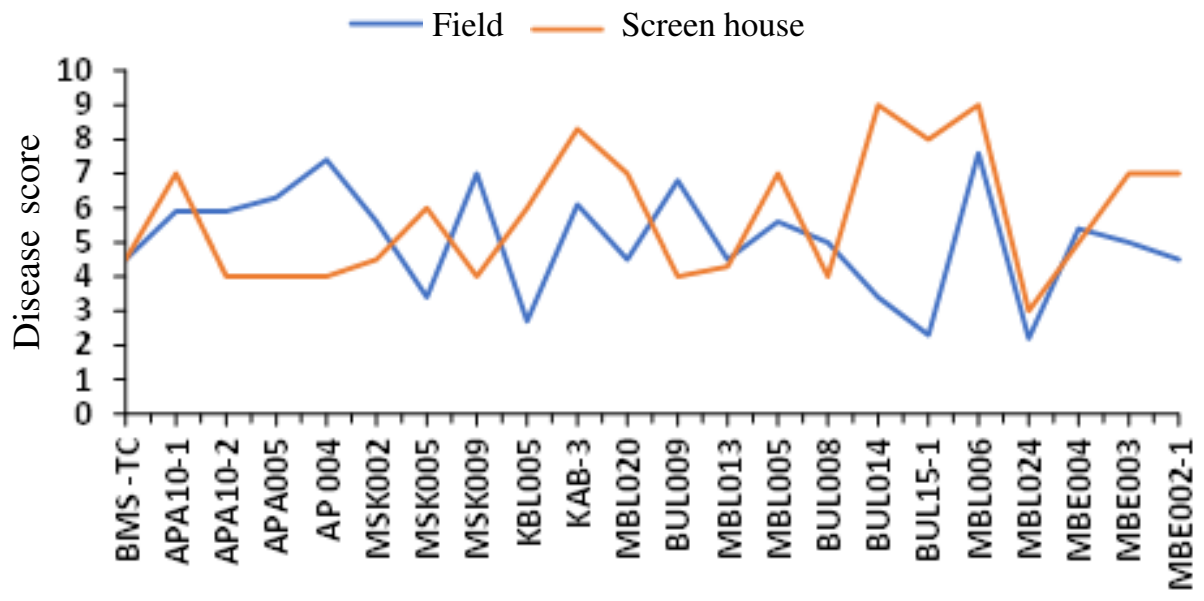

Isolate

Figure 1. Relationship between field disease severity and screen house severity scores of isolates.

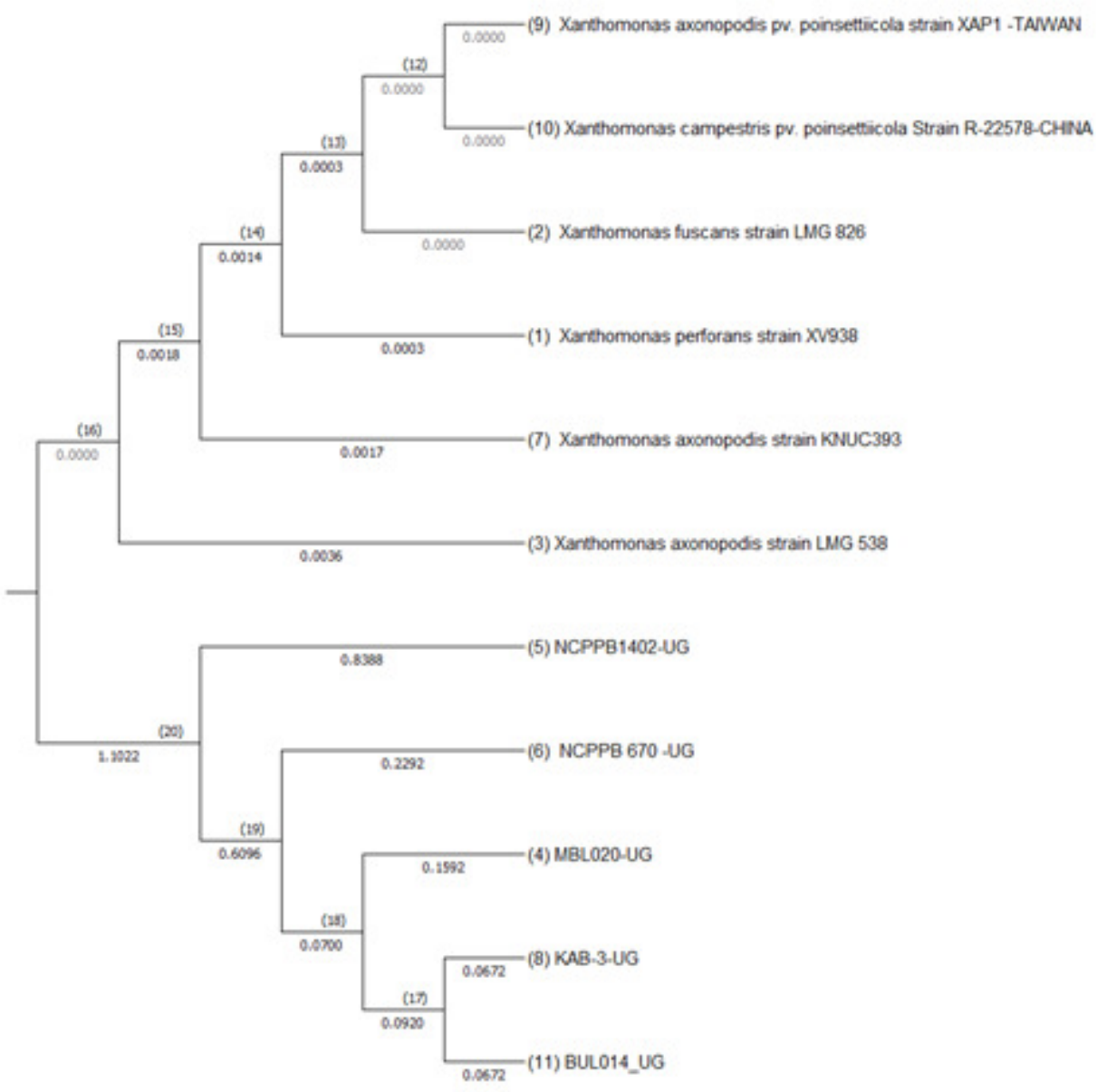

Figure 2. Comparison of 3 most virulent isolates of Xanthomonas from Uganda and those isolated previously from beans and other species based on 16s ribosomal gene. 


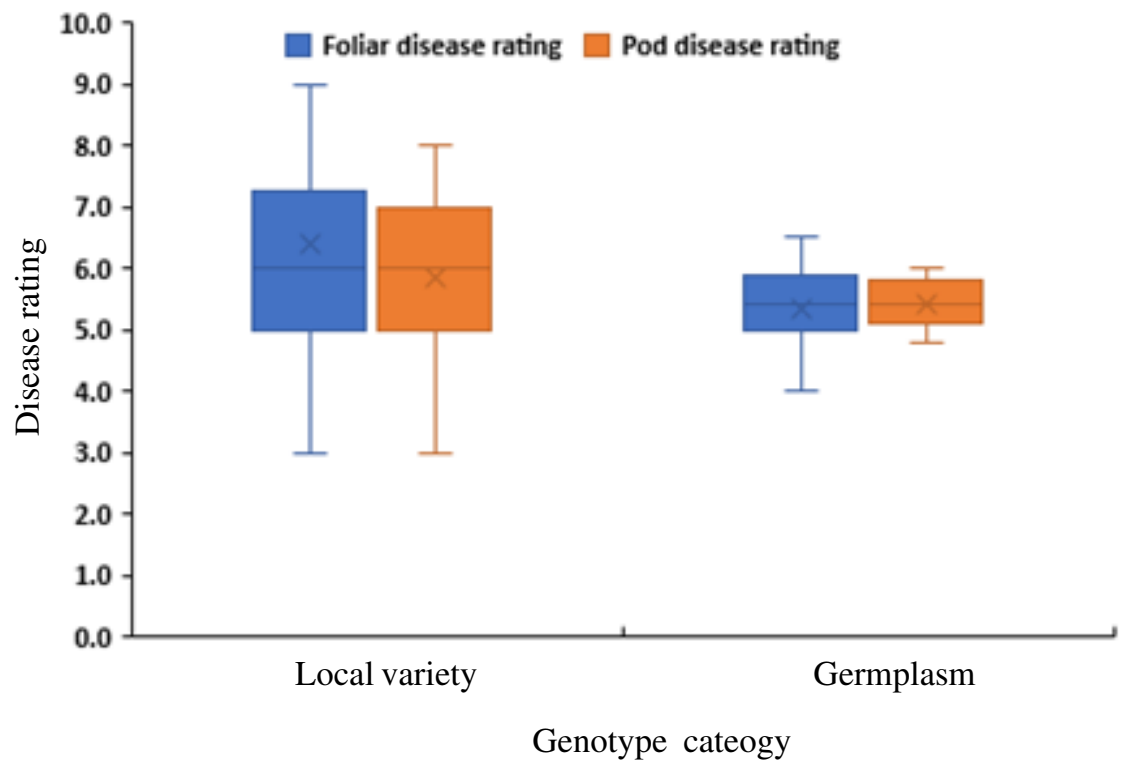

Figure 3. Foliar disease score on breeding germplasm and adopted bean genotypes in Uganda.

TABLE 4. Shows Reaction of bean breeding germplasm to MBL020 isolate of Xanthomonas citri pvfuscans

\begin{tabular}{lccl}
\hline Genotype & $\begin{array}{c}\text { Foliar disease rating } \\
(\text { 14 DAI })\end{array}$ & $\begin{array}{c}\text { Pod disease rating } \\
(10 \mathrm{DAI})\end{array}$ & Resistance rating \\
\hline A 197 & 5.7 & 5.1 & Moderate \\
ACC 10 & 5.9 & 5.8 & Moderate \\
ACC 4 & 5.2 & 5.9 & Moderate \\
ACC 5 & 6 & 6 & Susceptible \\
NE 2- 14- 8 & 4 & 5.3 & Moderate \\
NE 14-09-78 & 5.2 & 5.1 & Moderate \\
NE 17-14-29 & 5.5 & 5.1 & Moderate \\
MIB 465 & 5.4 & 5.4 & Moderate \\
NUA 45 & 6.5 & 5.5 & susceptible \\
VAX3 & 4.3 & 5.4 & Moderate \\
VAX 5 & 5 & 4.8 & Moderate \\
\hline
\end{tabular}

aggressive on some local varieties, which included NARONEAN1, NOROBEAN2 NAROBEAN 4, NABE15 and NABE 17; and unknown landrace, which had low foliar disease rating in comparison with other genotypes (Table 5). Pod resistance weakly correlated positively with foliar resistance, with $19 \%$ of the pod resistance explained by resistance in the leaves (Fig. 4). The exception to this relationship was that $\mathrm{K} 20$, NAROBEAN2, NABE 15 and 17 had low disease rating on leaves, but high on pods. The frequency of bean genotypes with moderate resistance was higher $(69.1 \%)$ compared to that of susceptible genotypes $(30.9 \%)$, in the tested breeding germplasm and local cultivar population. 
TABLE 5. Shows reaction of adopted bean cultivarsto MBL020 isolate of Xanthomonas citri pvfuscans

\begin{tabular}{lcll}
\hline Cultivar & $\begin{array}{c}\text { Foliar disease rating } \\
(14 \text { DAI })\end{array}$ & $\begin{array}{c}\text { Pod disease rating } \\
(10 \text { DAI })\end{array}$ & Resistance rating \\
\hline NABE 1 (OBA1) & 7.2 & 7.0 & Susceptible \\
Masindi Yellow & 8.0 & 6.0 & Susceptible \\
Kanyebwa & 8.3 & 6.0 & Susceptible \\
NABE3(MCM2001) & 6 & 5.7 & susceptible \\
K131 (MCM 5001) & 6.2 & 5.3 & Susceptible \\
K132(CAL96) & 5.7 & 5.3 & Moderate \\
K20(CAL 143) & 5.3 & 4.7 & Moderate \\
BUMUFU & 6.0 & 6.0 & susceptible \\
NABE26 & 6.0 & 5.3 & Moderate \\
BLACK & 5.9 & 5.7 & Moderate \\
Unknown & 3.8 & 4.3 & Moderate \\
NABE 14 & 6.0 & 4.3 & Susceptible \\
NABE6(UBR92) & 8.0 & 7.3 & Susceptible \\
Rushega & 8.6 & 7.7 & Susceptible \\
NABE 13 & 8.0 & 6.0 & Susceptible \\
NABE4(POA2) & 5.3 & 7.0 & Pod susceptible \\
NABE 16 & 7.0 & 6.1 & Susceptible \\
NABE2(MCM1015) & 7.0 & 4.3 & Pod resistant \\
NABE 17 & 5.6 & 7.0 & Pod susceptible \\
NABE 15 & 5.0 & 6.0 & Pod susceptible \\
K20 & 5.3 & 6.7 & Pod Susceptible \\
NAROBEAN 1 & 4.2 & 5.3 & Moderate \\
NAROBEAN2 & 4.3 & 6.5 & Pod susceptible \\
NAROBEAN3 & 7.3 & 4.5 & Susceptible \\
NAROBEAN4 & 5.0 & 6.7 & Moderate \\
NAROBEAN5 & 8.3 & Susceptible \\
NABE 12C & 9.3 & Susceptible \\
\hline & & &
\end{tabular}

Virulence of MBLO20 isolate. The virulence of Ugandan isolate (MBL020), like any other common bacterial blight pathogens isolated in other regions of the world, depended on the genotype and associated resistance sources. MBL020 was less virulent on infected genotypes containing SU91 and SAP6 as sources of resistance. Genotypes VAX3, VAX5 and ADP660 had foliar disease ratings, ranging between 3 to 4.5. MBL020 had a high foliar disease rating on genotypes containing SAP6 linked QTL as the source of resistance (Montcalm and MCM2001), with disease rating rangings of 5.5 to 6 , at 14 DAI (Fig. 5).

\section{DISCUSSION}

Virulence of Ugandan isolates. In contrast with Opio et al. (1996) who found fouscous phenotype being more dominat than the nonfuscous type, in the present study they existed almost in equal proportions (Table 2). However, isolates that gave high foliar disease severity score were of fuscous type, implying that they were more pathogenic than the nonfuscous type (Phaseoli).

The highest foliar disease severities in the field that occurred on varieties Mugagawale, 7.6, White small (NABE 6) 7.4 Nambale small 


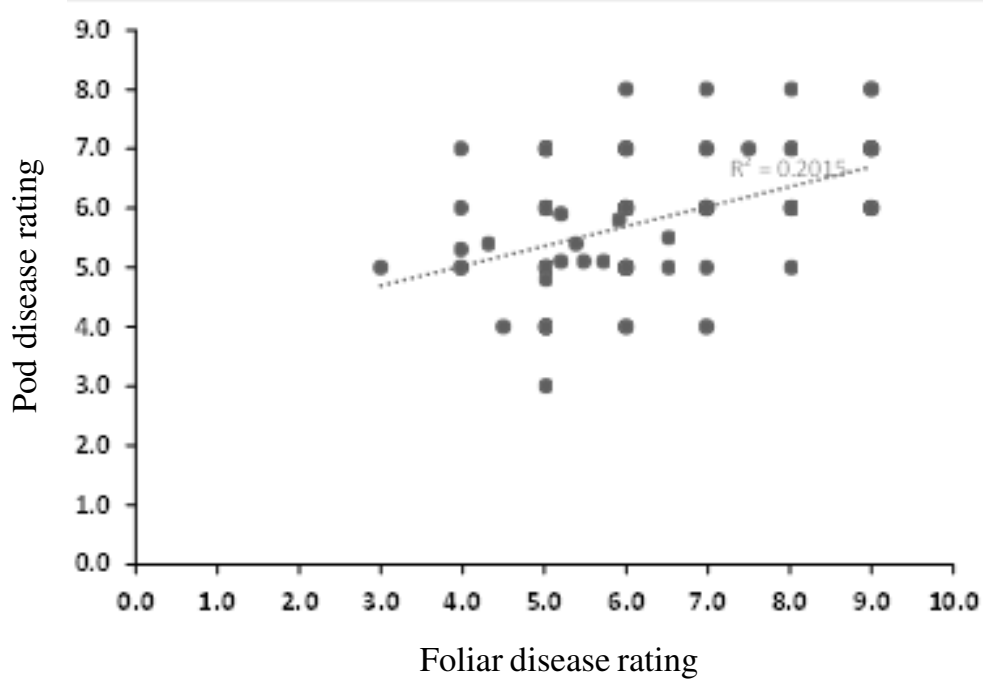

Figure 4. Relationship between foliar disease rating and pod disease rating among breeding and local varieties tested in screen house in Uganda.

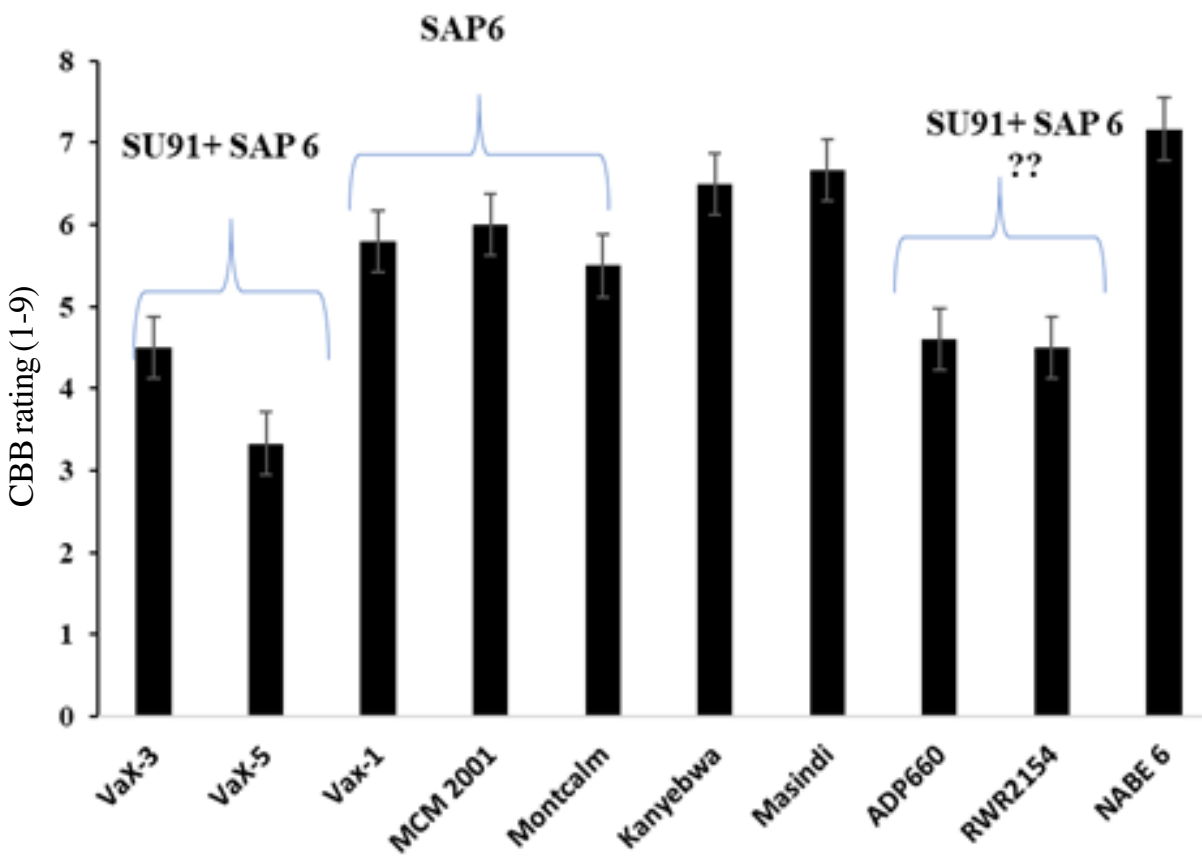

Genotype

Figure 5. Response of Selected resistance sources to the Ugandan isolate of common bacterial blight pathogen 14 days after inoculation 
(NABE 16) imply that these varieties were very susceptible. Continuous adoption of these varieties, despite their $\mathrm{CBB}$ adoption, remains a paradox but may be related to other attributes like cooking time and other culinary characteristics.

The occurrence of an isolate with disease score $>7$ in at least each agro-ecology when, tested under uniform screen house conditions, implies that variation in disease severity in different agro-ecologies could be a result of differences in varieties grown and local climatic conditions. On the other hand, two isolates (MBL020, KAB-3 and MSK005) which infected the most genotypes may reflect adaptation of these pathogens to both host and environment. Virulence of isolates in screen house was not correlated with virulence in the field where the pathogens were isolated (Fig. 1). This is not surprising condering that screen house conditions are uniform; while field condition are different in terms of variety and ecology. This research has, therefore, confirmed the hypothesis of the existence of more virulent strains of Xanthomonas on beans in Ugandan fields.

Phylogeny of most virulent isolates. Molecular comparison of these bacterial isolates with those previously isolated from Uganda, revealed the isolates to belong to Xanthomonas citri pvfuscans (current classification), formally Xanthomonas fuscans subs. fuscans. Isolate KAB-3 obtained from Kabarole in Uganda in the present study was highly similar to BUL014 obtained from Bulambuli Uganda (Fig. 2). This is not surprising considering the level of trade in bean grain, which in most cases doubles as seed in many farming communities in Uganda (Tugume et al., 2019).

Although KAB-3 and BUL014 were very closely related based on sequence similarity, MBL020 was slightly different from the two isolates. Phylogenomic analysis further revealed that the 3 isolates were closely related to bacteria, previously isolated from beans in
Uganda more than five decades ago (NCPPB1402 and NCPPB670).

This study, therefore, has shown that the occurrence of more virulent isolates in Uganda is endemic, dating back 1958 when the first Ugandan isolate of CBB was reported (Aritua et al., 2015). Comparative virulence tests of four strains of Xanthomonas phaseoli revealed that the Ugandan strain (U-2) was equally virulent as the two Columbian isolates C-6 and C-7, but more virulent than the Nabrasaka isolate XP-S (Schuster and Coyne, 1971; Schuster et al., 1973). However, these isolates may have been re-named, lost virulence or lost completely over the years.

Aritua et al. (2015) observed three distinct sub-lineages within the fuscan lineage including the European sub-lineage, American sublineage and African sub-lineage. The American and African sub-lineages are largely tropical isolates. The recently isolated pathogens belong to the African sub-lineage that includes isolates largely from Uganda and Ethiopia (Aritua et al., 2015). However, Aritua et al. (2015), observed fuscans isolates of African descent in Europe, which could be attributed to the work of Leakey during that period (19611973), where there were frequent bean germplasm exchanges between Uganda and UK. The differences among the NCPPB 1402 (1962) and NCPPB 670 (1958), and MBL020, KAB-3 and BUL014 imply that the divergence happened way back before the first isolation. Generally, bacterial isolates in this sub-lineage of fuscans lack XopG effector or that has been observed to elicite cell death, evading plant defense, thus contributing to more virulence. The continuous growing of susceptible varieties like Kanyebwa, black dwarf, NABE 6, K20 and NABE 16 could have helped preserve the status of these pathogens over the years.

Virulence of MBL020 isolate. Testing of the most aggressive Uganda isolate of Xanthomonas on widely used sources of resistance (those linked to SU91 and SAP6 
QTL markers), revealed moderate protection, and in some cases, susceptibility to this isolate. No genotypes could be categorised as resistant for both leaves and pods. Although SAP6 containing bean genotypes have previously shown resistance to some of the virulent tropical isolates like XCP123, they cannot be utilised as sole sources of resistance in the Ugandan bean breeding programme (Mutlu et al., 2008; Tugume et al., 2018). A combination of SU91 and SAP6, however, provides intermediate protection to this aggressive isolate. Since the aggressiveness of this isolate on NE 2-14-8 was comparable to that observed on VAX 3 and VAX 5 that are known to contain SAP6 and SU91, it may contain genes linked to these QTLs or other uncharacterised QTLS. Similarly, the higher frequency of bean genotypes with moderate resistance in breeding genotypes and local cultivars, implies that these genotypes may contain SU91 and SAP6 linked genes or other un characterised QTLs.

The existence of moderate resistance in some of Ugandan adopted varieties like NARONEAN1, NOROBEAN2, NABE14, NABE15 and NABE17 suggests that these genotypes may contain SU91 and SAP6 linked genes or other un characterised QTLs. Even though wide adoption of NAROBEAN varieties is still low due to their recent registration, they are promising for the future management of CBB in the country (National Variety List 2019). The observed association between foliar and pod resistance in breeding material and local varieties, though weak, reflect breeding effort towards dual $\mathrm{CBB}$ resistance.

The existence of moderate resistance among Andean bean genotypes, widely grown in Uganda, seems to be a common phenomenon. Leakey (1973) while working in Uganda also reported tolerance as opposed to immunity in genetic stocks at the time. Tolerance as opposed to complete resistance to Ugandan and Colombian isolates was also observed on PI207262, an important ancestor in the pedigree of CBB resistant genotypes (Schuster et al., 1973).
Isolate MBL020 which was identified in this study may be more virulent than the Xcp25, which has been widely used for screening and developing CBB-breeding lines in the USA (Ducan et al., 2011; Viteri et al., 2014); and also Kawempe 1 previously used by Alladasi et al. (2018). This is because a high resistance that was observed on genotypes VAX3 and VAX 5 when using XCP25 isolate, had moderate resistance when exposed to the Ugandan isolate MBL020 (Table 3).

\section{CONCLUSION}

The study identified 3 most virulent isolates, MBL020, KAB-3 and BUL-14, all belonging to Xathomonas citri pv fuscans. These isolates were very similar to those previously identified from Uganda (NCPB 670 and NCCPB 1402) more than 50 years ago. The study further revealed that NAROBEAN1, NAROBEAN 2, NAROBEAN 4, VAX 3, VAX5 and NE 2- 148 had better resistance compared to other tested genotypes.

\section{ACKNOWLEDGEMENT}

The authors are grateful for research funds from Higher Education, Science and Technology (HEST) project through CIAT, Uganda. Mr. Okii Dennis pre-reviewed the manuscript and the bean staff and personnel at CIAT, Kawanda provided various vital assistance.

\section{REFERENCES}

Alladassi, B.M.E., Nkalubo, S., Gibson, P., Edema,R., Urrea,C.A., Kelly, J.D. and Rubaihayo, P. 2018. Identification of common bean genotypes with dual leaf and pod resistance to Common Bacterial Blight Disease in Uganda. African Crop Science Journal 26(1):63-77.

Aritua, V., Harrison, J., Sapp, M., Buruchara, R. and Smith, J. 2015. Genome sequencing reveals a new lineage associated with lablab bean and genetic exchange between 
Xanthomonas axonopodis pv. phaseoli and Xanthomonas fuscans subsp. fuscans. Frontiers in Microbiology 6:1-18.

Castellanos, G., Jara, C. and Mosquera, N.D. Laboratory practice guides to managing pathogens Xanthomonas axonopodis pv. phaseoli (Common bacterial blight). Bean Pathology CIAT Library.

Cichy, K.A., Porch, T.G., Beaver, J.S., Cregan, P., Fourie, D., Glahn, R.P., Michael, A. Grusak, M.A., Kamfwa, K., Katuuramu, D.N., McClean, P., Nchimbi-Msolla, S., Marcial, A. Pastor-Corrales and Miklas, N.P. 2015. A Phaseolus vulgaris diversity panel for Andean bean improvement. Crop Science 55:2149-60.

Duncan, R., Shree, W., Singh, P. and Gilbertson, R.L. 2011. Interaction of common bacterial blight bacteria with disease resistance quantitative trait loci in common bean. Phytopathology 101(4): 425-35.

Karavina, C.R., Mandumbu, C.P. and Tibugari, H. 2011. A review of the occurrence, biology and management of Common Bacterial Blight. Journal of Agricultural Technology 7(6):1459-74.

Leakey, C.L.A. 1973. A note on Xanthomonas blight of beans (Phaseolus Vulgaris L.) Savi) and prospects for its control by breeding for tolerance. Euphytica 22:13233.

Mutlu, N., Vidaver, A.K., Coyne, D.P., Steadman, J.R., Lambrecht, P.A. and Reiser, J. 2008. Differential pathogenicity of Xanthomonas campestris pv. phaseoli and $X$. fuscans subsp. Fuscans strains on bean genotypes with common blight resistance. Plant Disease 92:546-554.

Opio, A.F., Allen, D.J. and Teri, J.M. 1996. Pathogenic variation in Xanthomonas
Campestris pv phaseoli, the causal agent of common bacterial blight in Phaseolus vulgaris. Plant Pathology 45:1126-33.

Schuster, M.L. and Coyne, D.P. 1971. New virulent strains of Xanthomonas phaseoli. Plant Disease Reporter 55(6):505.

Schuster, M.L., Coyne, D.P. and Hoff, B. 1973. Comparative virulence of Xanthomonas phaseoli strains from Uganda, Colombia, and Nebraska. Plant Disease Reporter 57:3486.

Thirumalai, C. and Manickam, V. 2017. Data analysis using box and whisker plot for lung cancer. In: International Conference on Innovations in Power and Advanced Computing. [i-PACT2017] pp. 1 - 6.

Tugume, J.K., Tusiime, G., Sekamate, A.M., Buruchara, R. and Mukankusi, C.M. 2018. Diversity and interaction of common bacterial blight disease-causing bacteria (Xanthomonas spp.) with Phaseolus vulgaris L. Crop Journal (7)1 - 7.

Tugume, J.K., Tusiime, G., Waswa, P., Mukankusi, C.M. and Buruchara, R. 2019. Distribution of common bacterial blight disease under different agro-ecologies in Uganda. African Crop Science Journal 27(2):295-306.

Viteri, D.M., Terán, H., Asensio, M.C., Manzanera, S., Asensio, C., Porch, T.G., Miklas, P.N. and Singh, S.P. 2014. A new common bacterial blight resistance QTL in VAX 1 common bean and interaction of the new QTL, SAP6 and SU91 with bacterial strains. Crop Science 54:15981608.

Viteri, D.M., Terán, H., Asensio, M.C., Manzanera, S., Asensio, C., Porch, T.G., Miklas, P.N. and Singh, S.P. 2014. Progress in breeding Andean common bean for resistance to common bacterial blight. Crop science 54:2084-2092. 